\title{
Varve formation since 1885 and high-resolution varve analyses in hypertrophic Baldeggersee (Switzerland)
}

\author{
A. F. Lotter ${ }^{1,2}$, M. Sturm ${ }^{2}$, J. L. Teranes ${ }^{3}$ and B. Wehrli ${ }^{2}$ \\ 1 University of Bern, Geobotanical Institute, Altenbergrain 21, CH-3013 Bern, Switzerland \\ 2 Swiss Federal Institute for Environmental Science and Technology (EAWAG), \\ CH-8600 Dübendorf, Switzerland \\ ${ }^{3}$ ETHZ, Geological Institute, Sonneggstrasse 5, CH-8092 Zürich, Switzerland
}

Key words: Lake sediments, eutrophication, grain-size, annually laminated sediments, geochemistry.

\section{ABSTRACT}

According to their microstratigraphical composition the laminated sediments of Baldeggersee are true varves. Two varve time-series from freeze cores taken in the deepest part $(66 \mathrm{~m})$ of Baldeggersee have been analysed for annual and seasonal layers. The varve time-series covers the period of 1885 to 1993.

The two freeze-cores from Baldeggersee can be accurately correlated by means of distinct layers (e.g. marker varves, turbidites), lithological units, and varve measurements. The Baldeggersee varve chronology has been checked by independent high-resolution ${ }^{137} \mathrm{Cs}$ dating. Mobility of cesium has not been detected in Baldeggersee. A highly positive correlation between phosphorus concentration in the lake water and median grain size of calcite crystals has been observed and allows, together with the results of geochemical analyses, to hindcast the trophic state in Baldeggersee for periods where no limnological data are available.

The main features of the Baldeggersee varve time-series can be summarized as follows: before 1885 there are packets of 5-10 varves interrupted by massive, homogeneous marl beds, indicating oscillating hypolimnetic oxygen levels until the lake ultimately became anoxic in 1885. Between 1885 and 1905 varves are thin, with a high carbonate content. Between 1905 and 1910 the thickness of varves increased steadily, and an increase in calcite grain size suggests a major step in eutrophication. Median grain size values increase again at the end of the 1940s, whereas the thickness of the seasonal layers decreased between the early 1940s and the early 1960s. At the onset of the 1960s, during the time of highest epilimnetic phosphorus concentrations in Baldeggersee, the total phosphorus concentrations in the sediments as well as the varve thickness and the total accumulation rates all increased. At the beginning of the 1980s the median grain size decreased substantially as a result of lower phosphorus concentrations in Baldeggersee.

\section{Introduction}

Annually laminated sediments have received much attention recently, as they allow the highest possible time-resolution (seasons to years) in long (centuries to millennia) proxy-data time series in sediment studies. A number of features make these 
deposits unique. First, they provide a dating of sediments that is independent of radiometric methods $\left(\right.$ e.g. ${ }^{137} \mathrm{Cs},{ }^{210} \mathrm{~Pb},{ }^{14} \mathrm{C}$ ), thereby also allowing extension of the dendrochronological radiocarbon calibration curve beyond its present limits of ca. 11 kyr (Hajdas et al., 1993; Wohlfarth et al., 1993; Goslar et al., 1995; Björck et al., 1996). Second, these sediments allow the most accurate estimates of rates of past environmental change during highly dynamic phases (e.g. Lotter et al., 1992; Goslar et al., 1993). Such estimates are especially important for understanding the reaction of natural systems to external forcing factors such as climate change (e.g. Zolitschka, 1996) or human impact (e.g. Peglar, 1993). And lastly, these sediments bear information about the environmental conditions in which they were deposited (Sturm and Lotter, 1995). The characteristics of annual laminations are strongly dependent on their ambient aquatic conditions (see e.g. O'Sullivan, 1983; Lotter and Sturm, 1993; Sturm and Lotter, 1995).

The term varve, originally coined for glaciolacustrine, annual laminations (De Geer, 1912) has also been widely used for different types of non-clastic, annual laminations (O'Sullivan, 1983; Simola, 1992). In fact, laminted lake sediments are often called varves. However, to qualify for this term the sediment must consist of two or more macro- or microscopically distinguishable layers that are deposited during the course of one year. Therefore, a first priority in studies of laminated sediments is to establish the seasonal nature of the layering. The presence of such laminations, as well as specific features of their formation, yields information about past environmental conditions such as climate (Perkins and Sims, 1983; Renberg et al., 1984; Leemann et al., 1991; Itkonen and Salonen, 1994) or trophic state of a lake (Simola et al., 1990).

As extensive limnological, sedimentological and climatological data are available for Baldeggersee, due to a restoration programme that started in 1982, this lake is an ideal site to study the processes of modern formation of biochemical varves.

The aims of this study were to prove the varved nature of the laminations, to establish a precise and high-resolution chronology for the laminated sediment, and eventually to assess the inter-annual variability in varve formation in terms of varve thickness and sediment geochemistry. For the first time, a high-resolution sampling of annual and seasonal layers combined with different high-resolution biostratigraphical and geochemical analyses for a time-span of $>100$ years have been carried out. Moreover, the assessment of different physical and geochemical varve features will enhance the understanding of sedimentation processes that may serve as a modern analogue for studies of century to millennia long biochemical varve time-series (e.g. Sturm and Lotter, 1995; Ralska-Jasiewiczowa et al., 1987).

\section{Site}

Baldeggersee is situated on the Swiss Plateau $\left(47^{\circ} 10^{\prime} \mathrm{N}, 8^{\circ} 17^{\prime} \mathrm{E}\right)$ in Central Switzerland at $463 \mathrm{~m}$ asl (Fig. 1). It has a water surface area of $5.2 \mathrm{~km}^{2}$, a max. depth of $66 \mathrm{~m}$ and a volume of $0.173 \mathrm{~km}^{3}$. Its watershed includes $67.8 \mathrm{~km}^{2}$, out of which $77 \%$ is intensively used agricultural land. The lake is fed by several small streams and the theoretical water residence time is 4.3 years (for details see Wehrli et al., 1997). 

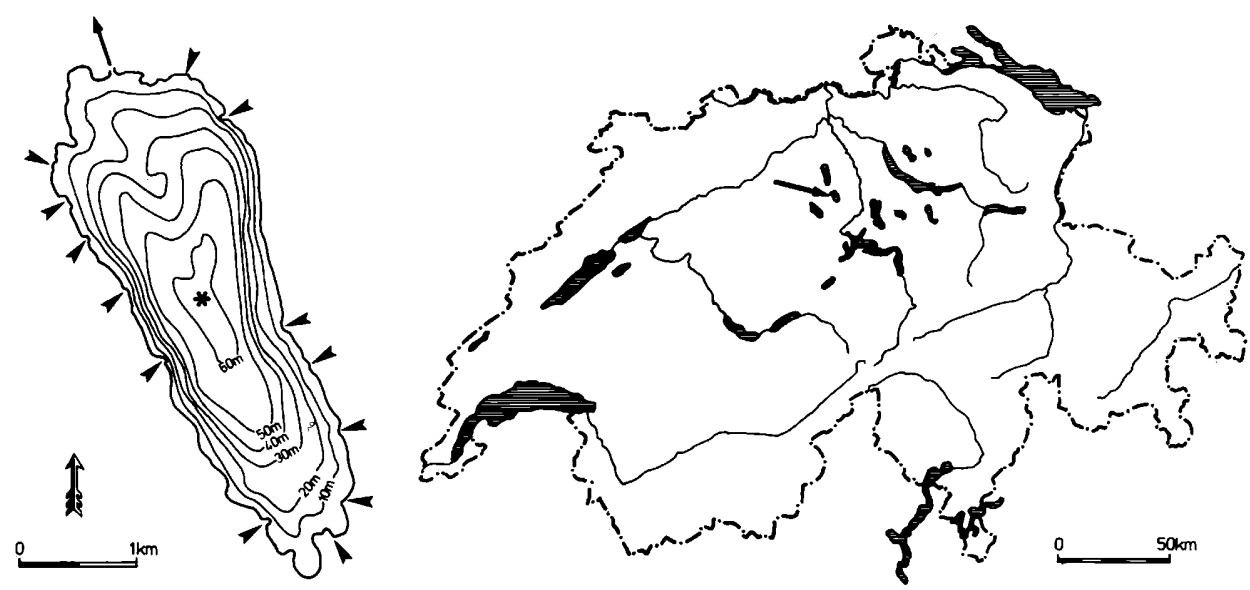

Figure 1. Map of Switzerland with location of Baldeggersee (arrow) and bathymetric map of Baldeggersee indicating the sampling point (star)

First investigations of Baldeggersee sediments were carried out in the early 1920s by Nipkow (1927) who recognised the potential of the laminated sediments as an independent dating tool. Niessen and Sturm (1987) mapped the distribution of laminated sediments in the basin and reconstructed the lake's eutrophication history. Due to its high nutrient concentrations and its permanently anoxic hypolimnion Baldeggersee has undergone lake restoration efforts since 1982. Alternately oxygen and air, during summer and winter respectively, are pumped into the deepest part of the lake at three locations to enhance mixing of the water and to reach the Swiss water quality standard of $4 \mathrm{mg} \mathrm{O}_{2} 1^{-1}$ for natural lakes.

\section{Methods}

In October 1993 three freeze cores (BA93-A, B, C) were taken in the deepest part of Baldeggersee at a water depth of $66 \mathrm{~m}$ (Fig. 1 and 2). A detailed account of the freeze-coring procedure is given by Lotter et al. (1997a). As core BA93-B broke in two parts during transport we sampled core BA93-B between the 1993 surface layer and the lower limit of the prominent 1956 turbidite (see Fig. 3) and then changed to core BA93-A for the sampling of the 1955-1885 layers. The results of these cores are therefore given as the combined BA93-BA series.

The frozen sediment was sawed into slabs of $4 \mathrm{~cm}$ width, freeze dried and then impregnated with SPURR's epoxy resin (see, e.g., Lamoureux, 1994). Thin-sections $70 \mathrm{~mm}$ long, $40 \mathrm{~mm}$ wide, and 25-30 $\mu \mathrm{m}$ thick were analysed under a low magnification binocular microscope using polarised light. After identification of varves in thin-sections of cores BA93-B and BA93-C, the layers were measured on enlarged thin-section photographs along two transects. Annual layers were sampled in core BA93-C by scratching them off the frozen sediment slab with paper cutter blades (see Lotter et al., 1997a). Additionally, in core BA93-BA the individual seasonal 


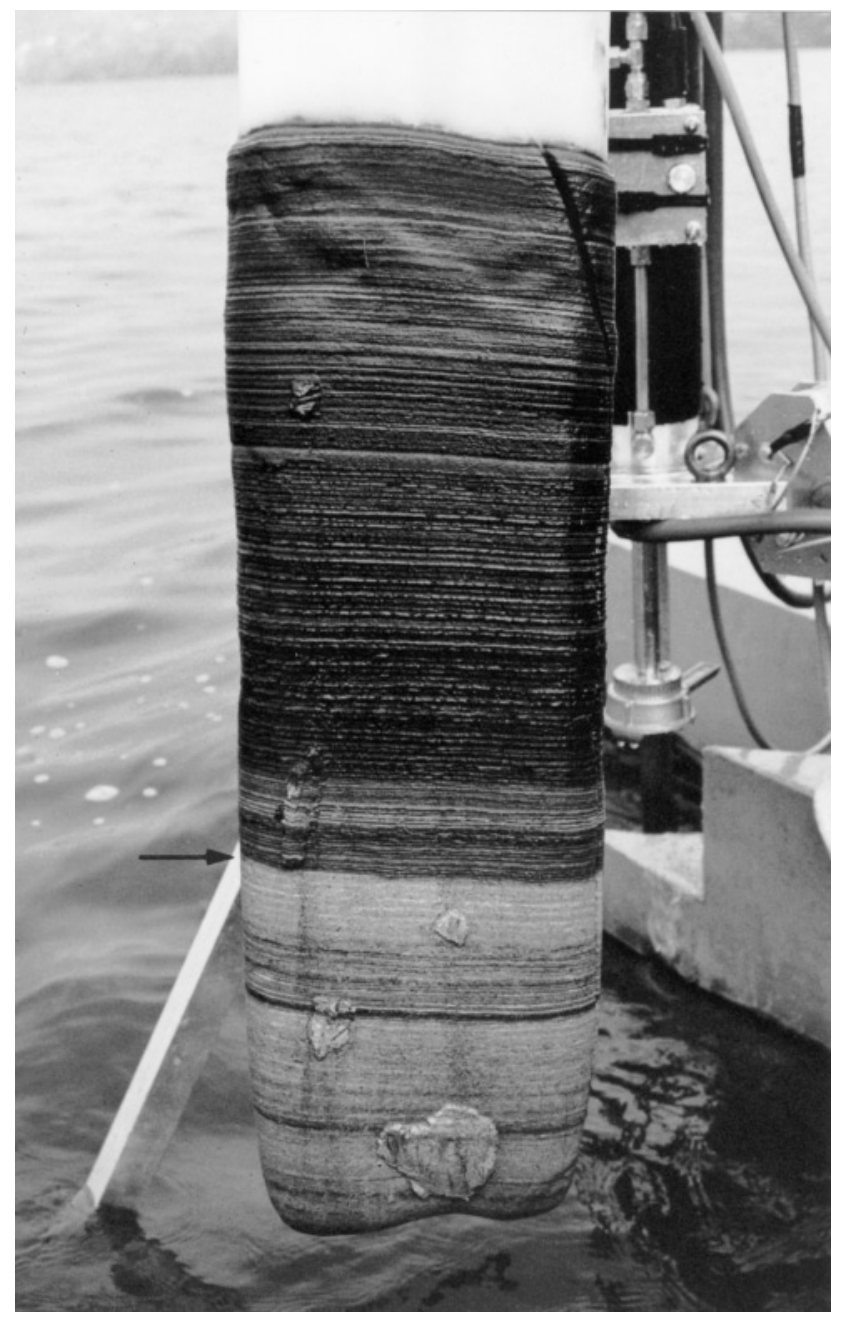

Figure 2. Overview over freeze core BA93-B showing the frozen water/sediment interface and the onset of annual laminations (arrow) in 1885

layers as well as the prominent turbidites were sampled separately. All sampling was carried out in a cold room at temperatures between $-20^{\circ} \mathrm{C}$ to $-15^{\circ} \mathrm{C}$.

The annual and the seasonal samples were weighed prior to and after freeze drying to estimate their water-content. On the basis of the surface area (width $x$ breath) and the dry weight, dry accumulation rates were calculated for each seasonal and annual layer.

The freeze-dried annual samples of core BA93-C were measured for radionuclides in a well-type Geli detector for a minimum of $24 \mathrm{~h}$. The isotopes ${ }^{134,137} \mathrm{Cs}$ were used to locate the characteristic activity maxima in 1963 (atmospheric bomb fallout) and 1986 (Chernobyl fall-out). 


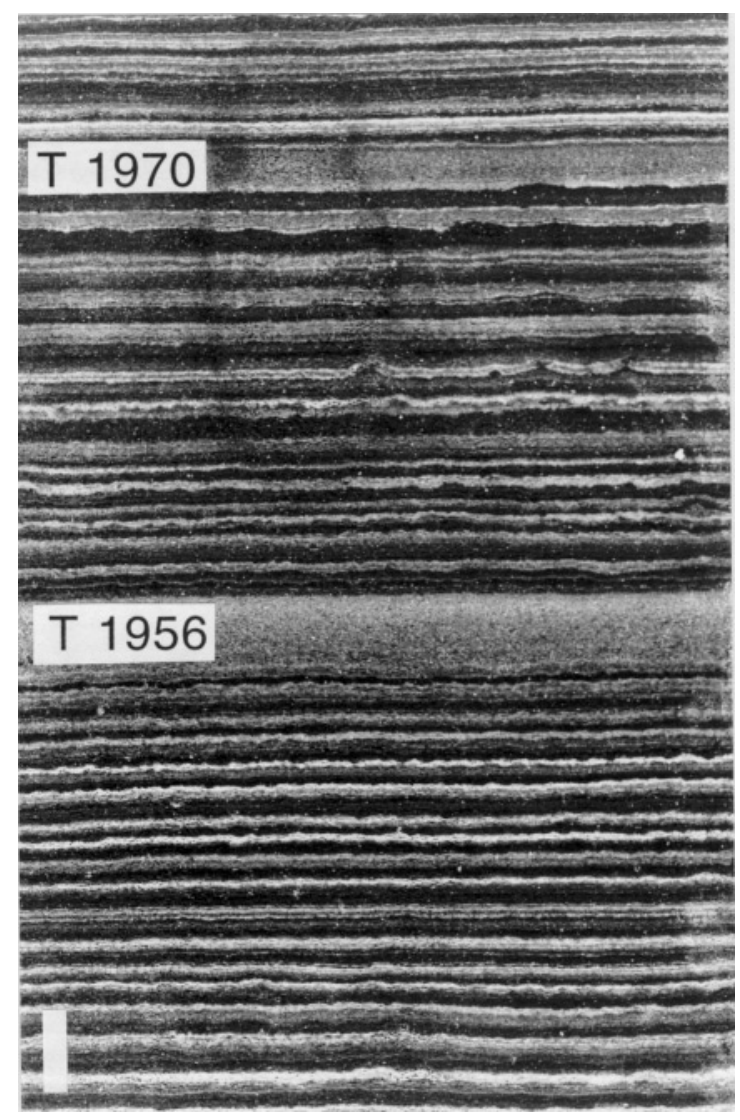

Figure 3. Core BA93-C showing the varves between 1974 to 1939 . The prominent 1970 and 1956 turbidites are labelled. The scale bar corresponds to $1 \mathrm{~cm}$

Total carbon (TC) and total nitrogen (TN) were analysed with a Carlo-Erba CNS analyser. Inorganic carbon (TIC) was measured using a Coulometer. Subtracting TIC from TC allows estimation of organic carbon (TOC). Total phosphorus (TP) was analysed using an autoanalyzer colorimeter.

Grain size distributions for individual years were determined by dispersing up to $2 \mathrm{~g}$ of freeze-dried material in a $0.1 \%$ solution of Calgon ${ }^{\circledR}$ and subsequently disintegrating with an ultrasonic microtip Branson Sonifier ${ }^{\circledR}$ for 4 minutes to avoid coagulation of particles. Grain sizes were measured with a Micromeritics Sedigraph ${ }^{\circledR} 5100$. This automated particle analyser uses a finely collimated, low energy X-ray beam, controlling the particle concentration in the measuring cell. Equivalent grain size diameters are calculated automatically by applying Stoke's law. 


\section{Lithology}

The freeze cores from the deepest part of Baldeggersee have a total sediment length of between 65 to $70 \mathrm{~cm}$ (Fig. 2). On the basis of the colour and appearance of the varves we subdivided the stratigraphy of the freeze cores into eight different lithological units (see Table 1).

Although varve measurements are possible for the entire laminated sequence, the quality and the thickness of the couplets largely determine how well the individual light and dark layer can be physically sampled. Below 1906 (lithological unit F) the couplets are very thin and the layers are often undulated. The contrast between the light and dark layer is often too low (see Fig. 4D) to allow an exact sampling of the seasonal layers. Therefore, the sampling of the layers older than 1906 may have an error in the order of one year. Nevertheless, varve identification and measurements on sediment thin-sections are still possible.

Table 1. Lithological units in Baldeggersee (see also Fig. 2)

\begin{tabular}{ll}
\hline A: $1993-1988$ & $\begin{array}{l}\text { unconsolidated, dark-brown sediment with thick couplets consisting of } \\
\text { several inconspicuous light layers }\end{array}$ \\
B: $1987-1983$ & $\begin{array}{l}\text { weakly consolidated, rust-brown to sienna brown sediment with several } \\
\text { conspicuous light layers per couplet }\end{array}$ \\
C: $1982-1970$ & $\begin{array}{l}\text { consolidated, brown sediment with two or three conspicuous light layers } \\
\text { per couplet (see Fig. 3) }\end{array}$ \\
D: $1969-1963$ & $\begin{array}{l}\text { consolidated, brown sediment with thicker couplets including two } \\
\text { conspicuous light layers (see Fig. 3) }\end{array}$ \\
E: $1962-1906$ & $\begin{array}{l}\text { consolidated, brown sediment with "normal" couplets including one or } \\
\text { sometimes two conspicuous light layers (see Fig. 3) }\end{array}$ \\
F: $1905-1895$ & $\begin{array}{l}\text { sienna brown sediment with couplets of light and smaller dark layers } \\
\text { brown sediment with undulated couplets of light and dark layers }\end{array}$ \\
G. $1894-1885$ & $\begin{array}{l}\text { light sediment with weak, inconspicuous large couplets of lighter and } \\
\text { darker layers and intermixed homogenous marl beds }\end{array}$ \\
H: 1884 &
\end{tabular}

\section{Microstratigraphy}

Thin-section analyses, as well as analyses of tape-peels of the frozen sediment (Simola et al., 1986), revealed the microstratigraphy of the laminae, and in connection with high-resolution sediment trap studies in Baldeggersee (Friedl and Sturm, pers. communication), prove that the laminated sediments are true varves.

Varves typical for lithological units A to E have a distinct microstratigraphy (see Fig. 4). The varves start with a layer of centric diatoms (Stephanodiscus and Cyclotella spp., see Lotter, in press) that can often only be discerned in the tape-peels and 

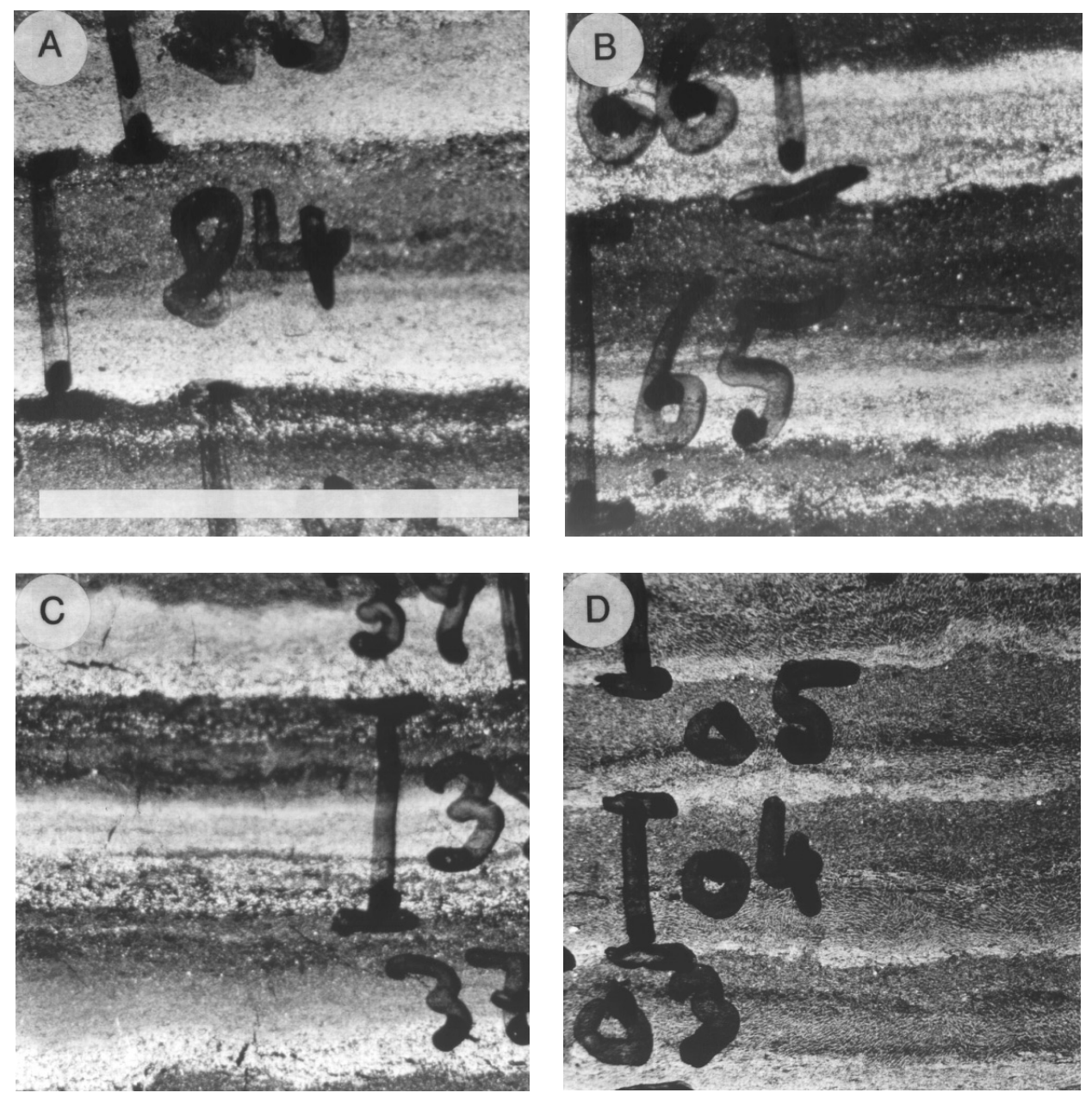

Figure 4. Photograph of thin-sections of varves from different lithological units: A. 1984; B. $1965 / 66$; C. $1937-1939$; D. $1903-1906$. The scale bar corresponds to $1 \mathrm{~cm}$

not in the thin-sections. Then the onset of the continuously graded light calcite layer follows, starting with large calcite crystals and subsequently decreasing in grain size (see, e.g., Fig. 4C). A second diatom bloom (e.g. Fragilaria crotonensis) can often be found intermixed in the small calcite fraction. The upper boundary of the light layer is often not conspicuous. The following dark layer consists of strongly decomposed organic fine-detritus and some fine calcite crystals (see Fig. 4).

According to high-resolution sediment trap studies (Kelts and Hsü, 1978; Sturm, 1985; Sturm and Friedl, pers. comm.), as well as biostratigraphical investigations in other varved sediments (Geyh et al., 1971; Dickman, 1985; Lotter, 1989; Simola, 1992), the large crystals are deposited by biologically induced calcite precipitation in spring. During the summer months, fine calcites are constantly precipitated, 
whereas during the autumn and winter months mainly organic matter such as dead algal biomass and detritus from higher vegetation (e.g. leaves) are deposited.

\section{Chronology}

Further evidence for an annual mechanism of deposition originates from independent measurements of ${ }^{137} \mathrm{Cs}$ in the annual layers of core BA93-C. The ${ }^{137} \mathrm{Cs}$ peaks of Chernobyl (1986), of the atmospheric nuclear weapon tests (1963), and of the onset of nuclear weapon tests (1955) correspond exactly to the according annual layers in the core (see Fig. 5). Further evidence for the accuracy of our varve chronology is the fact that the onset of the lamination in 1885 corresponds exactly to the results of Nipkow (1927), who, in 1925, counted 40 layers down to the onset of the laminations.

High porosity and low amount of clay minerals are reported to cause mobility of radionuclides in lake sediments (Crusius and Anderson, 1995). Although the Baldeggersee deposits show exceptionally high porosities and a very low clay mineral content our results give no evidence for post-depositional mobility of cesium. There-

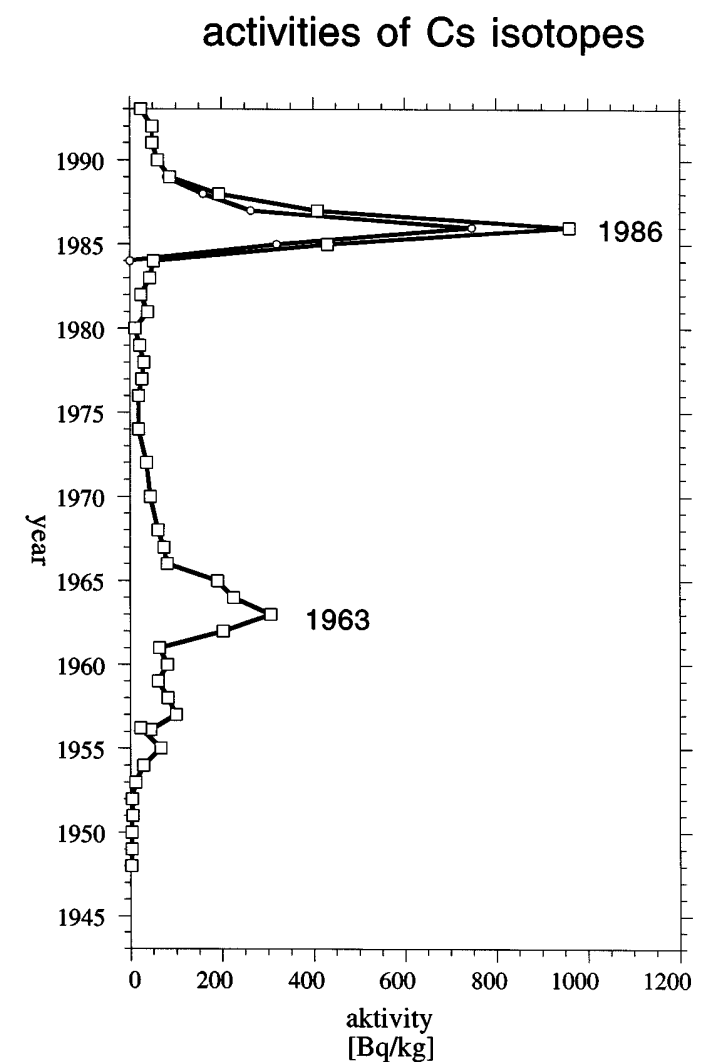

Figure 5. ${ }^{134} \mathrm{Cs}$ (open circles) and ${ }^{137} \mathrm{Cs}$ (open squares) profiles of core BA93-C. Measurements were performed on individual varves back to 1948 
fore, it can be assumed that hard-water environments (see also Wieland et al., 1993) like Baldeggersee are less prone to mobilization of nuclides than soft-water lakes.

\section{Varve measurements}

Replicate varve measurements have been carried out in two cores (Fig. 6). The layers in core BA93-BA are generally thicker and therefore also have higher accumu-
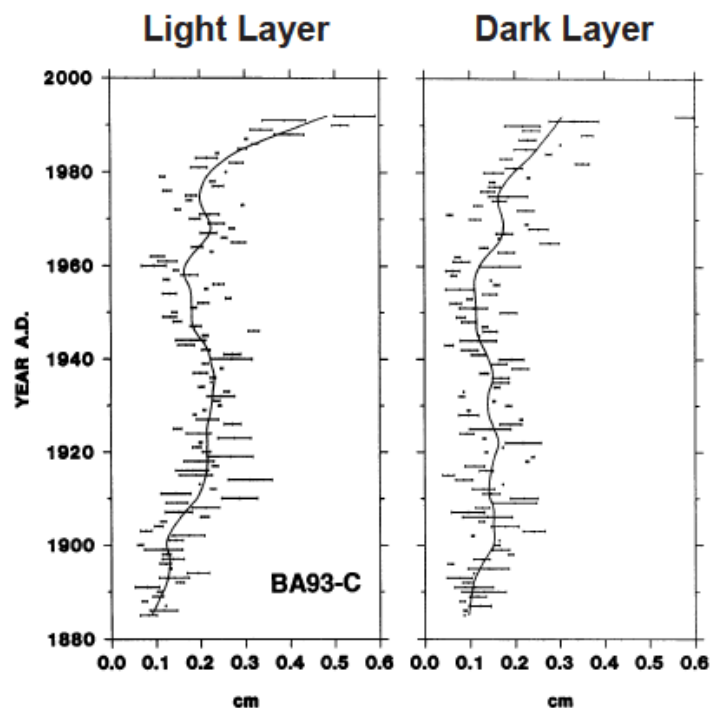

Total Layer
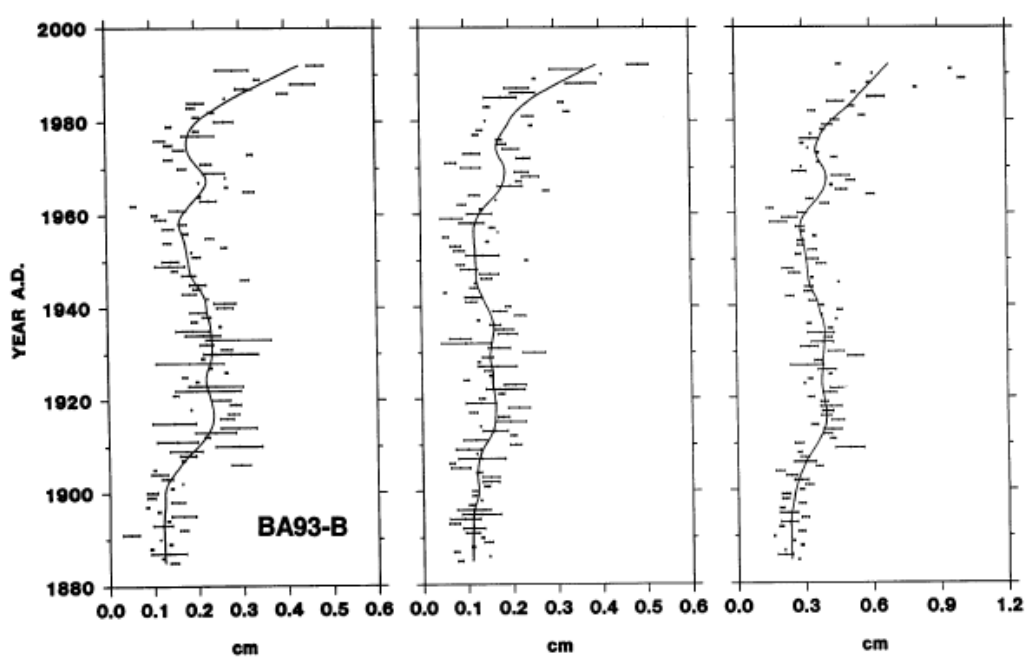

Figure 6. Replicate varve measurement in cores BA93-C and BA93-B. The error bars represent the standard deviation of two independent measurements and the line was plotted using a LOWESS function 


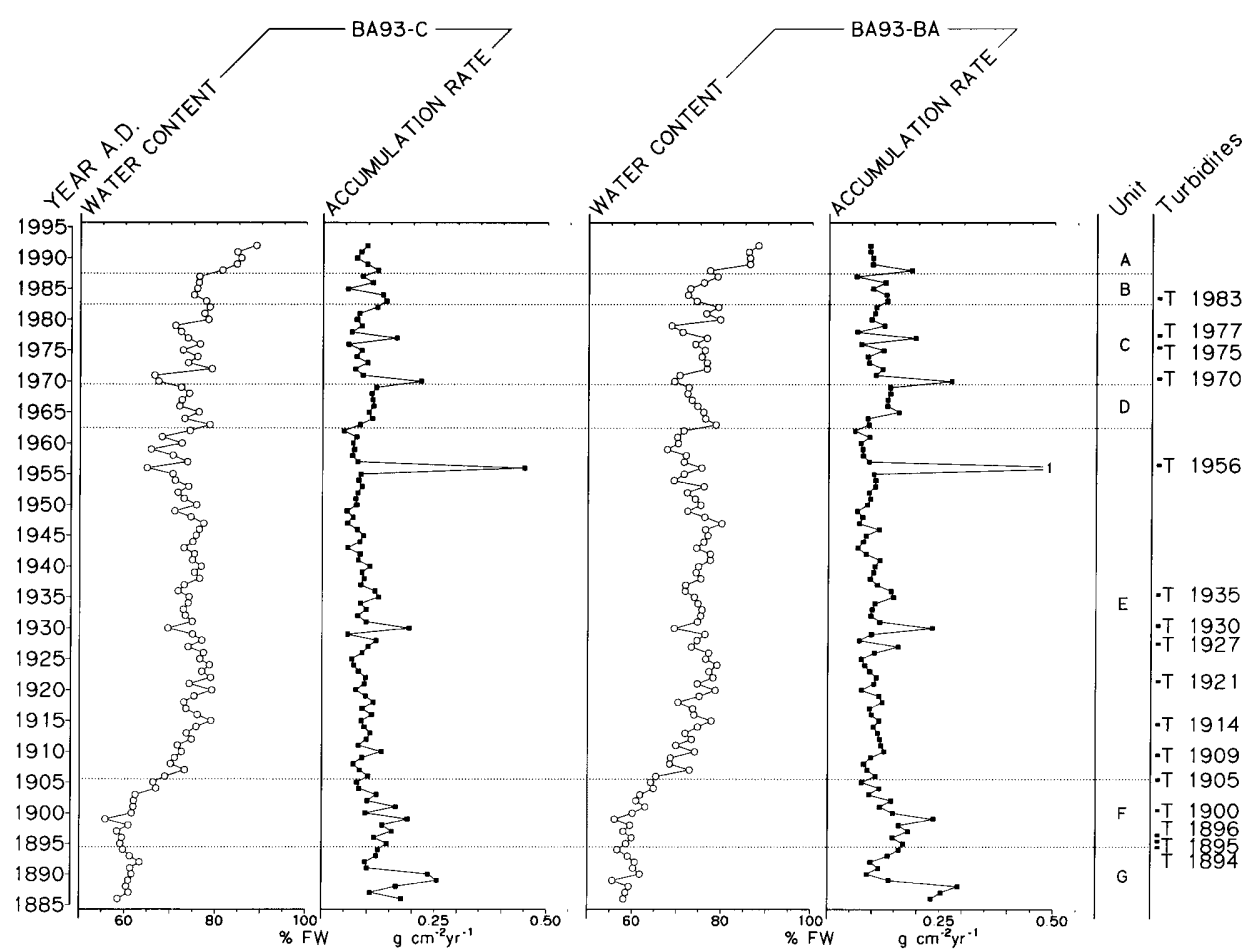

Figure 7. Water content (in $\%$ fresh weight) and dry accumulation rates for single varves in cores BA93-C and BA93-BA. Turbidites are marked on the right side of the diagram

lation rates than in core BA93-C (Fig. 7). Water contents of both cores compare well throughout all lithological units (Table 2). In general, the light layers are thicker than the dark layers (Fig. 6 and Table 2).

Relatively thick varves in lithological units A and B are simply the result of lower compaction in the topmost part of the sediment core. This observation is also manifested by high water content in unit $\mathrm{A}$ and no substantial increase in sediment accumulation throughout units A and B (see Figs. 7 and 8). According to the water content the varves in unit B seem as consolidated as in the underlying lithological units $\mathrm{C}, \mathrm{D}$, and $\mathrm{E}$.

Several phases of changes in varve thickness can be observed downcore. Between the early 1960s and 1970 (i.e. unit D, see also Fig. 3), as well as between ca. 1905 and the early 1940s (i.e. the lower part of unit E), the varves are thicker; varve thickness diminished between the early 1940s and the early 1960s (i.e. the upper part of unit E). Below 1910 (i.e. in units $F$ and $G$ ) the thinnest varves are observed. 
Table 2. Average and standard deviation for different varve features and geochemistry in the different lithological units

\begin{tabular}{|c|c|c|c|c|c|c|c|c|c|}
\hline Parameter & core & $\begin{array}{l}\text { Total core } \\
1992-1885\end{array}$ & $\begin{array}{l}\text { Unit A } \\
1993-1988\end{array}$ & $\begin{array}{l}\text { B } \\
1987-1983\end{array}$ & $\begin{array}{l}\text { C } \\
1982-1970\end{array}$ & $\begin{array}{l}\text { D } \\
1969-1963\end{array}$ & $\begin{array}{l}\text { E } \\
1962-1906\end{array}$ & $\begin{array}{l}F \\
1905-1895\end{array}$ & $\begin{array}{l}\mathrm{G} \\
1894-1885\end{array}$ \\
\hline \multirow[t]{2}{*}{ light layer (cm) } & BA93-C & $0.20 \pm 0.08$ & $0.44 \pm 0.09$ & $0.28 \pm 0.05$ & $0.21 \pm 0.06$ & $0.24 \pm 0.03$ & $0.20 \pm 0.05$ & $0.12 \pm 0.03$ & $0.12 \pm 0.04$ \\
\hline & BA93-B & $0.21 \pm 0.08$ & $0.43 \pm 0.12$ & $0.27 \pm 0.08$ & $0.20 \pm 0.06$ & $0.25 \pm 0.04$ & $0.21 \pm 0.05$ & $0.12 \pm 0.03$ & $0.12 \pm 0.03$ \\
\hline \multirow[t]{2}{*}{ dark layer $(\mathrm{cm})$} & BA93-C & $0.16 \pm 0.08$ & $0.35 \pm 0.15$ & $0.24 \pm 0.05$ & $0.17 \pm 0.07$ & $0.20 \pm 0.05$ & $0.13 \pm 0.05$ & $0.15 \pm 0.05$ & $0.10 \pm 0.02$ \\
\hline & ВА93-В & $0.16 \pm 0.07$ & $0.37 \pm 0.09$ & $0.22 \pm 0.06$ & $0.18 \pm 0.07$ & $0.21 \pm 0.05$ & $0.14 \pm 0.05$ & $0.12 \pm 0.02$ & $0.11 \pm 0.03$ \\
\hline \multirow[t]{2}{*}{ total layer $(\mathrm{cm})$} & BA93-C & $0.36 \pm 0.14$ & $0.78 \pm 0.21$ & $0.52 \pm 0.08$ & $0.38 \pm 0.09$ & $0.44 \pm 0.08$ & $0.34 \pm 0.08$ & $0.27 \pm 0.04$ & $0.22 \pm 0.04$ \\
\hline & BA93-B & $0.37 \pm 0.14$ & $0.73 \pm 0.24$ & $0.58 \pm 0.14$ & $0.38 \pm 0.07$ & $0.44 \pm 0.11$ & $0.35 \pm 0.08$ & $0.25 \pm 0.06$ & $0.23 \pm 0.05$ \\
\hline accumulation rate & BA93-C & $105 \pm 50.9$ & $94.9 \pm 17.9$ & $104.7 \pm 34.7$ & $98.3 \pm 45.1$ & $106.3 \pm 11.7$ & $93.7 \pm 53.0$ & $125.6 \pm 35.6$ & $160.4 \pm 59.7$ \\
\hline$\left(\mathrm{mg} \mathrm{cm}^{-2} \mathrm{yr}^{-1}\right)$ & BA93-BA & $121 \pm 64.5$ & $112.7 \pm 40.1$ & $108.8 \pm 29.5$ & $119.4 \pm 56.2$ & $124.4 \pm 26.1$ & $108.8 \pm 70.6$ & $143.6 \pm 43.9$ & $167.2 \pm 72.9$ \\
\hline light layer & BA93-BA & $65.4 \pm 19.8$ & $73.8 \pm 17.3$ & $61.2 \pm 31.2$ & $62.5 \pm 14.0$ & $90.2 \pm 19.0$ & $63.8 \pm 14.9$ & $63.8 \pm 30.6$ & $60.1 \pm 25.2$ \\
\hline dark layer & BA93-BA & $40.1 \pm 33.9$ & $39.0 \pm 25.2$ & $31.1 \pm 17.6$ & $32.0 \pm 14.4$ & $34.2 \pm 10.5$ & $30.5 \pm 15.2$ & $62.7 \pm 33.5$ & $94.5 \pm 80.3$ \\
\hline \multirow{2}{*}{ water content $(\% \mathrm{FW})$} & BA93-C & $72.0 \pm 6.6$ & $84.9 \pm 2.7$ & $76.2 \pm 1.0$ & $74.0 \pm 4.1$ & $74.1 \pm 2.5$ & $73.8 \pm 3.0$ & $61.3 \pm 3.3$ & $60.5 \pm 1.7$ \\
\hline & BA93-BA & $71.9 \pm 7.0$ & & $74.8 \pm$ & & & $73.9 \pm 3.1$ & $60.7 \pm$ & $58.9 \pm 1.9$ \\
\hline water content light layer & BA93-BA & $67.0 \pm 6.6$ & $81.5 \pm 4.5$ & $69.4 \pm 7.2$ & $67.1 \pm 5.4$ & $65.8 \pm 2.9$ & $68.8 \pm 4.1$ & $59.5 \pm 2.8$ & $56.5 \pm 2.2$ \\
\hline water content dark layer & BA93-BA & $76.9 \pm 8.3$ & $87.8 \pm 4.4$ & $80.2 \pm 3.6$ & $82.0 \pm 2.8$ & $83.7 \pm 2.8$ & $79.0 \pm 3.5$ & $61.8 \pm 2.9$ & $61.3 \pm 2.3$ \\
\hline $\mathrm{TC}\left(\mathrm{g} \mathrm{kg}^{-1}\right)$ total layer & BA93-C & $109.0 \pm 11.8$ & $127.1 \pm 4.2$ & $116.1 \pm 3.5$ & $112.0 \pm 9.2$ & $118.4 \pm 2.6$ & $108.2 \pm 11.6$ & $100.4 \pm 9.3$ & $98.6 \pm 10.3$ \\
\hline light layer & BA93-BA & $110.0 \pm 16.9$ & & $114.1 \pm 17.9$ & $123.0 \pm 6.7$ & $122.7 \pm 7.3$ & $112.0 \pm 11.9$ & $88.0 \pm 16.7$ & $88.5 \pm 21.5$ \\
\hline dark layer & BA93-BA & $101.6 \pm 13.1$ & $122.0 \pm 7.7$ & $117.3 \pm 13.4$ & $109.9 \pm 13.4$ & $108.6 \pm 6.5$ & $95.9 \pm 11.4$ & $105.0 \pm 5.0$ & $96.3 \pm 6.2$ \\
\hline TIC $\left(\mathrm{g} \mathrm{kg}^{-1}\right)$ total layer & BA93-C & $78.3 \pm 9.7$ & $74.7 \pm 7.5$ & $72.3 \pm 4.5$ & $75.3 \pm 8.3$ & $80.8 \pm 4.6$ & $79.7 \pm 10.8$ & $78.4 \pm 9.3$ & $77.2 \pm 10.0$ \\
\hline light layer & BA93-BA & $87.5 \pm 17.3$ & $83.7 \pm 9.8$ & $83.1 \pm 28.7$ & $97.7 \pm 6.1$ & $93.4 \pm 6.9$ & $92.2 \pm 12.9$ & $65.5 \pm 17.4$ & $71.6 \pm 22.5$ \\
\hline dark layer & BA93-BA & $57.4 \pm 15.1$ & $55.7 \pm 22.2$ & $64.6 \pm 15.7$ & $43.7 \pm 8.1$ & $44.0 \pm 9.9$ & $54.6 \pm 9.7$ & $83.5 \pm 7.4$ & $73.6 \pm 6.0$ \\
\hline TOC $\left(\mathrm{g} \mathrm{kg}^{-1}\right)$ total layer & BA93-C & $30.7 \pm 8.6$ & $52.3 \pm 9.0$ & $43.9 \pm 5.5$ & $36.7 \pm 3.2$ & $37.6 \pm 3.1$ & $28.5 \pm 4.6$ & $22.0 \pm 2.2$ & $21.4 \pm 1.3$ \\
\hline light layer & BA93-BA & $22.3 \pm 6.6$ & $35.8 \pm 5.5$ & $31.0 \pm 11.6$ & $25.3 \pm 4.2$ & $29.3 \pm 3.8$ & $19.6 \pm 4.1$ & $22.5 \pm 4.2$ & $16.9 \pm 2.6$ \\
\hline dark layer & BA93-BA & $44.2 \pm 17.1$ & $66.3 \pm 18.4$ & $52.7 \pm 5.8$ & $66.3 \pm 10.4$ & $64.6 \pm 9.0$ & $41.3 \pm 9.8$ & $21.5 \pm 3.9$ & $22.7 \pm 3.7$ \\
\hline $\mathrm{TN}\left(\mathrm{g} \mathrm{kg}^{-1}\right)$ & BA93-C & $3.2 \pm 1.3$ & $6.7 \pm 1.5$ & $4.8 \pm 0.7$ & $4.2 \pm 0.6$ & $4.3 \pm 0.3$ & $2.7 \pm 0.8$ & $2.2 \pm 0.3$ & $2.1 \pm 0.1$ \\
\hline $\mathrm{TP}\left(\mathrm{g} \mathrm{kg}^{-1}\right)$ & BA93-C & $0.71 \pm 0.22$ & $0.95 \pm 0.24$ & $0.89 \pm 0.10$ & $0.99 \pm 0.11$ & $0.88 \pm 0.16$ & $0.64 \pm 0.17$ & $0.60 \pm 0.17$ & $0.49 \pm 0.05$ \\
\hline $\mathrm{Ca}\left(\mathrm{g} \mathrm{kg}^{-1}\right)$ & BA93-C & $286.8 \pm 35.1$ & $273.4 \pm 25.9$ & $259.2 \pm 18.1$ & $277.9 \pm 32.1$ & $304.9 \pm 20.3$ & $288.8 \pm 36.8$ & $293.2 \pm 37.7$ & $287.9 \pm 40.2$ \\
\hline $\operatorname{Mg}\left(\mathrm{g} \mathrm{kg}^{-1}\right)$ & BA93-C & $6.5 \pm 1.9$ & $5.7 \pm 0.8$ & $6.9 \pm 0.7$ & $6.6 \pm 1.7$ & $5.5 \pm 0.6$ & $6.2 \pm 1.8$ & $7.4 \pm 2.2$ & $8.6 \pm 2.0$ \\
\hline Grain size, median $(\mu \mathrm{m})$ & BA93-C & $6.46 \pm 3.49$ & $9.39 \pm 2.27$ & $8.87 \pm 1.10$ & $11.13 \pm 1.98$ & $12.66 \pm 2.74$ & $5.21 \pm 1.81$ & $2.69 \pm 0.17$ & $2.49 \pm 0.15$ \\
\hline
\end{tabular}




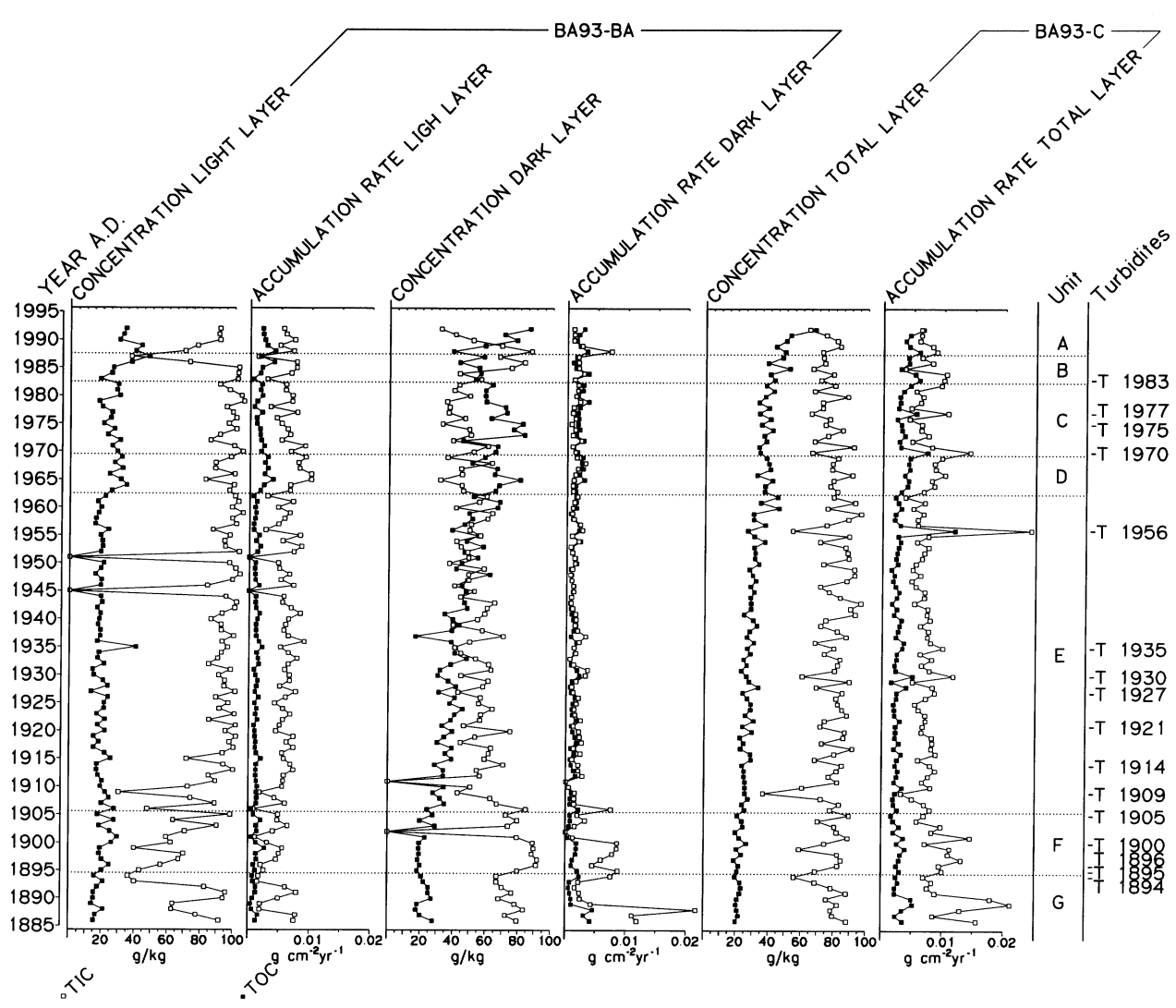

Figure 8. Organic (TOC) and inorganic carbon (TIC) concentrations and accumulation rates in cores BA93-C and BA93-BA. For core BA93-BA each seasonal layer has been analysed separately

\section{Accumulation rates}

The sampling of individual varves in core BA93-C and the sampling of single seasonal layers in core BA93-BA allowed an accurate and high-resolution estimate of both water content and accumulation rates (Fig. 7).

Water content decreases in two major steps from the top to the bottom of the core. The first step occurs between lithological units A and B and represents the effect of sediment compaction, whereas the second step, occurring between units $\mathrm{E}$ and $\mathrm{F}$, reflects a decrease in organic matter in the lower part of the core.

Curves of the total accumulation rates (Fig. 7) are similar in both cores, although core BA93-BA has slightly higher accumulation rates overall (see Table 2). Single peaks in the total accumulation rates, such as the ones in 1977, 1970, 1956, and 1930, can be attributed to the presence of distinct turbidites.

In lithological units $\mathrm{F}$ and $\mathrm{G}$, as well as in unit $\mathrm{D}$, the accumulation rates are generally higher due to the higher amount of inorganic carbon. 


\section{Carbon, nitrogen, and phosphorus}

High-resolution carbon measurements show that TOC concentrations increase steadily towards the top of the cores, principally in the dark layers (Fig. 8). The light layers are dominated by inorganic carbon, both in concentrations and accumulation rates, whereas the dark layers are characterised by higher amounts of organic carbon (Fig. 8). The concentration of TIC, reflecting the carbonate content, remains more or less constant throughout the profile, except in units $F$ and $G$ where it increases. In the light layers of unit F the TIC is lower than in the rest of the profile, whereas in the dark layers of the same unit the TIC values are higher. We attribute this to a sampling artifact: due to the low organic content in unit $\mathrm{F}$, the contrast between the dark and light layers is low, thus making an accurate sampling of the seasonal layers difficult. In this part of the core, a substantial amount of the light layer has obviously also been scratched off together with the dark layer. This result exemplifies the limits of this sampling method in sediments with a low contrast between the seasonal layers.

TN and TP have been analysed for the total layers in core BA93-C (Fig. 9). In the period from the mid-1930s to the early 1960s TN concentrations have constantly

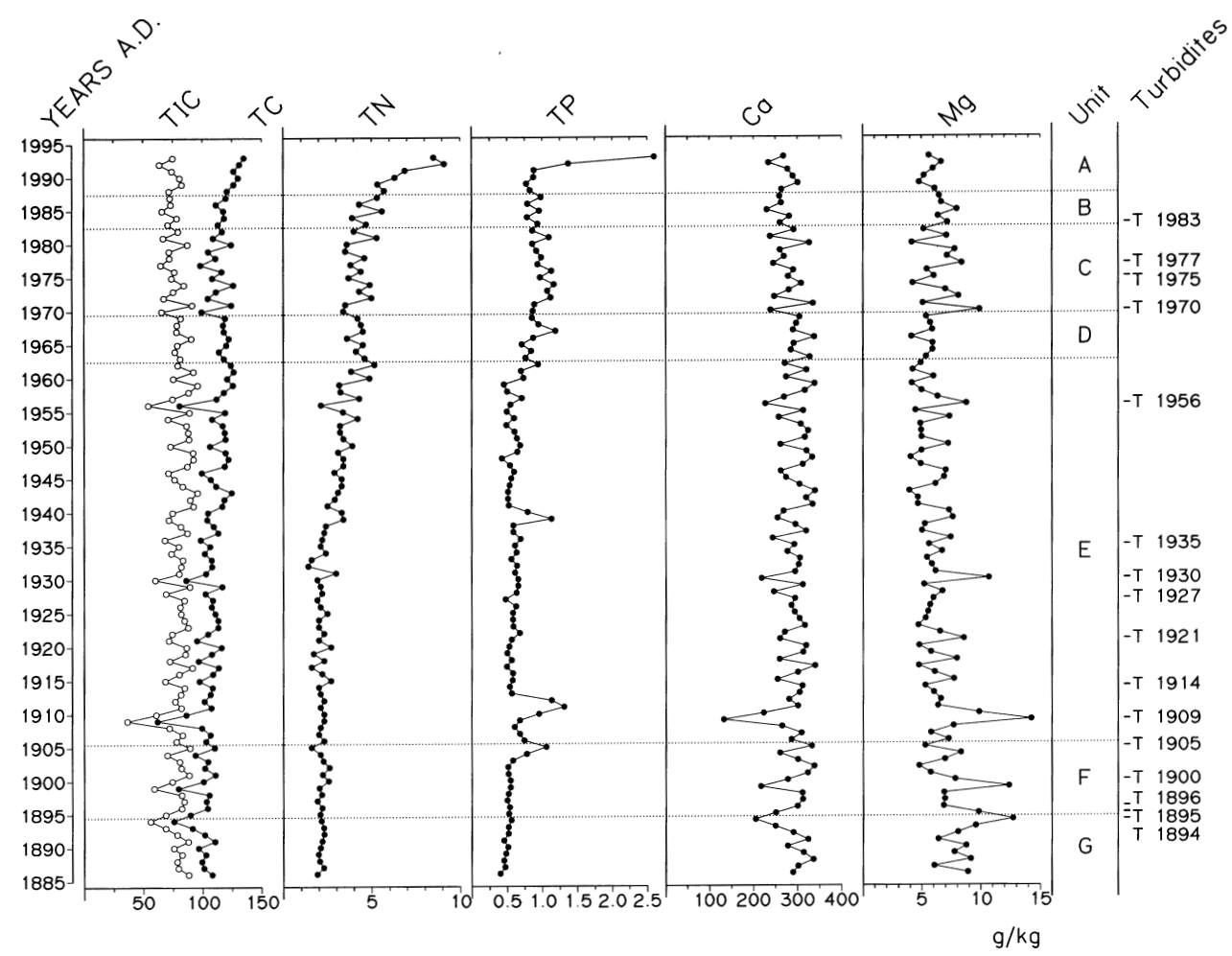

Figure 9. Geochemical analyses in annual layers of core BA93-C. The location of turbidites is marked on the right side of the diagram 
increased from 2 to $4.5 \mathrm{~g} \mathrm{~N} \mathrm{~kg}^{-1}$. If we disregard the most recent layers, where the mineralization of organic matter is still occurring at high rates, the TN remained rather constant since the 1960s. The TN-concentrations may reflect both an increase in total sedimentation rate of biomass due to high phosphorus loading and a decrease in mineralization rates as a consequence of deep water anoxia (Wehrli et al., 1997). Based on this concept, the TOC (Fig. 8) and TN (Fig. 9) data indicate that primary productivity reached high levels in the 1960s and organic matter preservation was enhanced due to hypolimnetic anoxia. As expected, the concentration of inorganic nitrogen in the water column is rather decoupled from the sediment concentrations. The time series of inorganic nitrogen in the water column of Baldeggersee shows a more steady increase by a factor of ten in the last 40 years (see Wehrli et al., 1997).

In contrast to nitrogen, the TP concentrations in the sediments show a significant increase at the beginning of the 1960s. The sediment data represent only a "damped" version of the chemical trend in the water column (see Wehrli et al., 1997). The average phosphorus concentrations in Baldeggersee increased fivefold between the 1950s to the mid 1970s, when a maximum of more than $500 \mathrm{mg} \mathrm{P} \mathrm{m}^{-3}$ was observed around 1975 in the water column. The sediment concentration increased roughly twofold between 1955 and 1975. Since then a slight decrease is observed.

The overall features of cores BA93-BA and BA93-C show high correlation coefficients (see Table 3). However, the correlations for each lithological unit are not constant. Generally, the correlation between the thickness of the light layers is higher in all units except in unit $\mathrm{C}$. The higher variability in the dark layers between the cores may be the result of a higher variability in the formation of dark layers or a sampling artifact. The correlation in units $F$ and $G$ are small because of the above mentioned sampling problems that led to the variability in the varve features, whereas the lower correlations in the topmost unit A are most likely the effect of differential sediment compaction (see Lotter et al., 1997b).

Table 3. Correlation coefficients for different varve features between core BA93-C and BA93-BA

\begin{tabular}{lrlllll}
\hline core unit & $\mathrm{n}$ & light layer & dark layer & total layer & $\mathrm{H}_{2} \mathrm{O}$ content & $\begin{array}{l}\text { dry accumulation } \\
\text { rate }\end{array}$ \\
\hline total core & 109 & $0.93^{1}$ & $0.84^{1}$ & $0.95^{1}$ & $0.95^{1}$ & $0.84^{1}$ \\
unit A & 5 & $0.76^{4}$ & $0.72^{5}$ & 0.62 & $0.87^{2}$ & -0.36 \\
unit B & 5 & $0.93^{2}$ & $0.75^{3}$ & $0.90^{2}$ & 0.26 & $0.67^{5}$ \\
unit C & 13 & $0.92^{1}$ & $0.95^{1}$ & $0.96^{1}$ & $0.82^{1}$ & $0.94^{1}$ \\
unit D & 7 & $0.94^{1}$ & $0.91^{1}$ & $0.96^{1}$ & $0.75^{3}$ & 0.44 \\
unit E & 58 & $0.86^{1}$ & $0.64^{1}$ & $0.96^{1}$ & $0.76^{1}$ & $0.97^{1}$ \\
unit F & 11 & 0.46 & 0.42 & $0.64^{3}$ & $0.96^{1}$ & $0.72^{2}$ \\
unit G & 10 & $0.50^{5}$ & 0.28 & $0.37^{2}$ & $0.68^{3}$ & 0.07 \\
\hline
\end{tabular}

1 significant correlation at the $0.05 \%$ level.

2 significant correlation at the $0.5 \%$ level.

3 significant correlation at the $1 \%$ level.

${ }^{4}$ significant correlation at the $2.5 \%$ level.

5 significant correlation at the $5 \%$ level. 
Carbon, nitrogen and phosphorus are highly correlated (significant at the $0.05 \%$ level, Table 4). The C:N and C:P atomic ratios are rather constant before 1960 and change only in the top sections of the freeze cores. The values shown in Table 2 indicate average C: $\mathrm{N}$ atomic ratios of 9.1, 12.3 and 11.9 for the periods 1993-1988, $1962-1906$ and $1895-1885$, respectively. Nitrogen is preferentially released during the diagenetic processes that occur within the first years after sedimentation (Urban et al., 1997). Release of phosphorus to the overlying water is more rapid than mineralization of organic matter, because an important fraction of phosphorus is transported in the form of iron particles to the sediment surface (Hupfer et al., 1995). Therefore, the C:P ratio decreases downcore from $142(1993-1988)$ to 115 and 113 (1962-1906 and 1895-1885, respectively).

The freeze core profiles (Fig. 8 and Fig. 9) illustrate the dynamics of diagenetic reactions at the deepest point of the lake. The high concentrations of TOC and TN in the most recent layer (1993) decrease within 3-4 years to a rather constant level. Elevated TP concentrations are observed only in the last two years. These observations are supported by pore-water profiles (Urban et al., 1996; Furrer and Wehrli, 1996) which indicate an active zone of mineralization by $\mathrm{Fe}, \mathrm{Mn}, \mathrm{SO}_{4}^{2-}$ in the top few centimetres of the sediment. Below that zone only the slower mineralization pathway of methanogenesis is active.

The concentration of TOC and nutrients in the freeze cores can be compared with data from a sediment mapping study that included 38 gravity cores described by Schaller and Wehrli (1996). Table 5 compares average values for TOC, TN and TP in three sections of the gravity cores with the corresponding sections of the freeze core BA93-C. In general, the freeze core data are in good agreement with the corresponding results from the gravity cores averaged for the whole lake, thus indicating that the trends in carbon, nitrogen and phosphorus obtained from the freeze core at the deepest point of the lake (Fig. 9) can be extrapolated, with some caution, to the whole basin.

Only the topmost sediment section of the freeze core yields significantly higher values of TOC and TN compared to the average values for the sediment mapping study. This discrepancy probably reflects differences in bioturbation. Due to artificial oxygenation benthic organisms (such as oligochaetes and chironomids) were able to recolonize the surficial sediment down to a water depth of $50 \mathrm{~m}$ (Spengeler, 1994). As a consequence, no varves are discernible in the top section of the gravity cores taken at water depths above $50 \mathrm{~m}$ (Schaller and Wehrli, 1996). Typically, the top $5-10 \mathrm{~cm}$ of these gravity cores have been homogenized by bioturbating organisms, thus enhancing the mineralization rates (Svensson and Leonardson, 1996; Gächter and Wehrli, pers. communication). The TOC concentration actually decreased in the topmost section of the gravity cores $\left(25 \pm 8 \mathrm{~g} \mathrm{~kg}^{-1}\right)$ compared to the varved section just below $\left(31 \pm 7 \mathrm{~g} \mathrm{~kg}^{-1}\right)$. Thus, the presence of oxygen at the sediment surface, together with bioturbation has lowered the burial rate of carbon by ca. $20 \%$. Therefore, at least in productive lakes, the presence of oxygen is an important factor governing burial rates of organic carbon, a fact that has been the subject of an intense scientific debate in the oceanographic literature (Henrichs, 1992; Canfield, 1994; Mayer, 1994). 
Table 4. Pearson correlation matrix for varve features and various sediment properties in core BA93-C $(n=82)$

\begin{tabular}{|c|c|c|c|c|c|c|c|c|c|c|c|c|c|}
\hline & $\begin{array}{l}\text { light } \\
\text { layer }\end{array}$ & $\begin{array}{l}\text { dark } \\
\text { layer }\end{array}$ & $\begin{array}{l}\text { total } \\
\text { layer }\end{array}$ & $\begin{array}{l}\text { water } \\
\text { content }\end{array}$ & $\begin{array}{l}\text { accumul. } \\
\text { rate }\end{array}$ & TC & TIC & TOC & $\mathrm{TN}$ & $\mathrm{TP}$ & $\mathrm{Ca}$ & $\mathrm{Mg}$ & $\begin{array}{l}\text { grain } \\
\text { size }\end{array}$ \\
\hline $\begin{array}{l}\text { light layer } \\
\text { dark layer } \\
\text { total layer } \\
\text { water content } \\
\text { accumulation rate } \\
\text { TC } \\
\text { TIC } \\
\text { TOC } \\
\text { TN } \\
\text { TP } \\
\text { Ca } \\
\text { Mg } \\
\text { grain size }\end{array}$ & 1 & $\begin{array}{l}0.60 \\
1\end{array}$ & $\begin{array}{l}0.91 \\
0.88 \\
1\end{array}$ & $\begin{array}{l}0.71 \\
0.49 \\
0.68 \\
1\end{array}$ & $\begin{array}{l}-0.15^{*} \\
-0.03^{*} \\
-0.11^{*} \\
-0.42 \\
1\end{array}$ & $\begin{array}{c}0.46 \\
0.33 * \\
0.44 \\
0.57 \\
-0.44 \\
1\end{array}$ & $\begin{array}{c}-0.01 * \\
-0.23 * \\
-0.11 * \\
0.10^{*} \\
-0.36 \\
0.72 \\
1\end{array}$ & $\begin{array}{c}0.64 \\
0.73 \\
0.76 \\
0.69 \\
-0.21 * \\
0.61 \\
-0.21 * \\
1\end{array}$ & $\begin{array}{c}0.58 \\
0.71 \\
0.71 \\
0.60 \\
-0.20 * \\
0.59 \\
-0.10 * \\
0.95 \\
1\end{array}$ & $\begin{array}{c}0.27 * \\
0.44 \\
0.39 \\
0.37 \\
-0.20 * \\
0.27 * \\
-0.21 * \\
0.62 \\
0.61 \\
1\end{array}$ & $\begin{array}{c}-0.03^{*} \\
-0.25^{*} \\
-0.15^{*} \\
0.06^{*} \\
-0.27^{*} \\
0.68 \\
0.96 \\
-0.13^{*} \\
-0.11^{*} \\
-0.20^{*} \\
1\end{array}$ & $\begin{array}{c}-0.31 * \\
-0.07 * \\
-0.22 * \\
-0.53 \\
0.44 \\
-0.87 \\
-0.84 * \\
-0.28^{*} \\
0.22^{*} \\
-0.07 * \\
-0.82 \\
1\end{array}$ & $\begin{array}{l}0.38 \\
0.32 * \\
0.39 \\
0.54 \\
-0.07 * \\
0.57 \\
0.12 * \\
0.68 \\
0.67 \\
0.49 \\
0.14 * \\
-0.41 \\
1\end{array}$ \\
\hline $\mathrm{n}$ & 108 & 108 & 108 & 108 & 108 & 108 & 108 & 108 & 108 & 107 & 107 & 107 & 82 \\
\hline
\end{tabular}

* not significant at the $5 \%$ level (Bonferroni corrected). 
Table 5. Comparison of freeze core data $\left[\mathrm{g} \mathrm{kg}^{-1}\right]$ with average values from 38 gravity cores taken at different depths of Baldeggersee

\begin{tabular}{|c|c|c|c|c|c|c|}
\hline \multirow[t]{2}{*}{ Parameter } & $\begin{array}{l}\text { freeze core } \\
\text { BA93-C }\end{array}$ & gravity cores & $\begin{array}{l}\text { freeze core } \\
\text { BA93-C }\end{array}$ & $\begin{array}{l}\text { gravity } \\
\text { cores }\end{array}$ & $\begin{array}{l}\text { freeze core } \\
\text { BA93-C }\end{array}$ & gravity cores \\
\hline & $\begin{array}{l}1992-1988 \\
\text { section A }\end{array}$ & top section & $\begin{array}{l}1962-1906 \\
\text { section } E\end{array}$ & $\begin{array}{l}\text { varved } \\
\text { sediment }\end{array}$ & $\begin{array}{l}1895-1885 \\
\text { section G }\end{array}$ & $\begin{array}{l}<1900 \\
\text { homogeneous } \\
\text { grey marl }\end{array}$ \\
\hline TOC & $52.3 \pm 9.0$ & $25 \pm 8$ & $28.5 \pm 4.6$ & $31 \pm 7$ & $21.4 \pm 1.3$ & $22 \pm 10$ \\
\hline TN & $6.7 \pm 1.5$ & $2.8 \pm 1.0$ & $2.7 \pm 0.8$ & $3.3 \pm 0.8$ & $2.1 \pm 0.1$ & $2.2 \pm 1.0$ \\
\hline TP & $0.95 \pm 0.24$ & $0.82 \pm 0.16$ & $0.64 \pm 0.17$ & $0.77 \pm 0.14$ & $0.49 \pm 0.05$ & $0.45 \pm 0.1$ \\
\hline
\end{tabular}

\section{Carbonate, calcium and magnesium}

Each individual varve in core BA93-C has been analysed for several geochemical parameters (see also Schaller et al., 1997). The whole profile is dominated by high Ca concentrations (Fig. 9) that correlate closely with the TIC values (Table 4). Based on the average values in Table 2 for the whole core, calcite $\left(\mathrm{CaCO}_{3}\right)$ forms the dominant mineral in the sediment with a content of about 70 wt.\%. TOC and organic matter $\left(\right.$ as $\left.\left(\mathrm{CH}_{2} \mathrm{O}\right)_{11} \mathrm{NH}_{3}\right)$ contribute 3 and $8 \mathrm{wt} . \%$, respectively. The ratio of inorganic to organic carbon (TIC:TOC) is 1.4 in the top section of the core and increases to 3.6 in the layers deposited 100 years ago. Two mechanisms contribute to this change in the TIC:TOC ratio: mineralization of organic matter mobilizes TOC without affecting TIC, and allochthonous input of carbonate particles is likely to have contributed to carbonate sedimentation in sediment sections F and G, as evidenced by the high TIC accumulation rates in the dark layers of core BA93-BA (Fig. 8).

Throughout the whole core the TIC:Ca ratio is 0.91 which indicates that other ions such as $\mathrm{Fe}^{2+}, \mathrm{Mn}^{2+}$ and $\mathrm{Mg}^{2+}$ contribute to the formation of carbonate minerals. Major fluctuations in the $\mathrm{Ca}$ values are mainly due to the presence of turbidites. Many of the annual layers containing turbidites (Fig. 3) also show high Mg concentrations. In lake sediments from the Swiss Plateau higher values in Mg may be used as a good indicator for allochthonous input. The two parameters $\mathrm{Ca}$ and $\mathrm{Mg}$ are inversely correlated (Table 4). The average $\mathrm{Ca}: \mathrm{Mg}$ ratio is 26.8. Due to allochthonous input, the $\mathrm{Ca}: \mathrm{Mg}$ ratio in turbidites can be as low as 6.7 (e.g. T1909 in Fig. 9). Most turbidites in Baldeggersee originate from its watershed and are carried to the lake by heavy rainfall and/or flooding events.

Below 1905 the sampling of the layers shows an off-set of one year. This is evident from the $\mathrm{Mg}$ peaks originating from distinct turbidites: the turbidites of 1905, 1900, and 1896-1894 show their expected Mg peaks one layer deeper. Specifically, it was difficult to separate out the turbidites during sampling in this lithological unit due to the low contrast between the individual layers. The turbidite of 1905, for instance, had been sampled with the 1904 layer, as it was too difficult to identify it accurately macroscopically. 


\section{Grain Size Distribution}

In this study we concentrate on the median grain size (MGS) to characterize particle size evolution in Baldeggersee during the last 110 years. Figure 10 summarises the results of these measurements. It can be clearly recognized that MGS have increased substantially since 1885 . Four major phases can be distinguished in the sedimentary record of Baldeggersee.

Phase 1. Prior to 1910 small MGS values $(<3 \mu \mathrm{m})$ prevail. Minimum grain sizes of microcrystalline calcites are around $1 \mu \mathrm{m}$.

Phase 2. Between 1910 and 1950 MGS values are nearly double pre-1910 values $(5-6 \mu \mathrm{m})$. The distinct $\mathrm{min} / \mathrm{max}$ variations are between $2 \mu \mathrm{m}$ and $7 \mu \mathrm{m}$. This is mainly the effect of an increase in the size-class of $10-20 \mu \mathrm{m}$ (see Fig. 10).

Phase 3. Between 1950 and 1980 enhanced coarsening of calcites occurs, with MGS values around $12 \mu \mathrm{m}$. Large min/max variations $(9 / 16 \mu \mathrm{m})$ also occur. During this phase it is mainly the size-class of $20-60 \mu \mathrm{m}$ that increases substantially.

Phase 4. The period between 1980 and 1993 is dominated by an apparent decrease in MGS to about $8 \mu \mathrm{m}$ and then an increase again to about $11 \mu \mathrm{m}$. The contribution of the $10-20 \mu \mathrm{m}$ size-class remains constant, whereas the abundance of the bigger, $20-60 \mu \mathrm{m}$ grains diminishes.

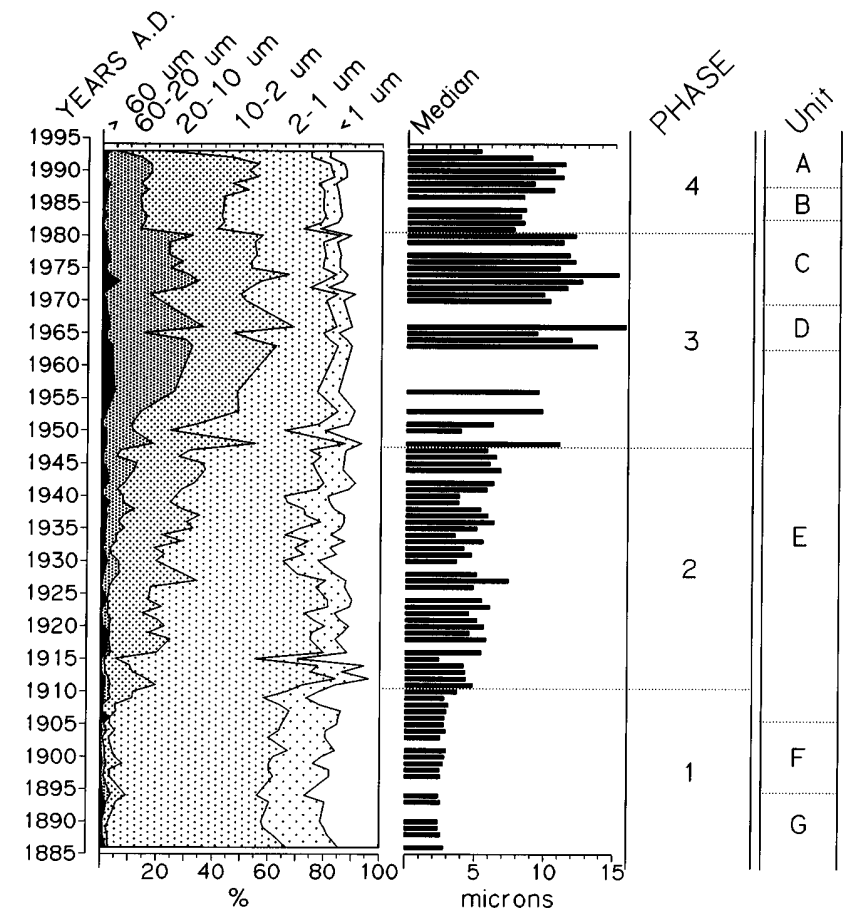

Figure 10. Grain size distribution in core BA93-C as cumulative diagram and as median grain size. The change to coarser grain sizes by enhanced eutrophication around 1950 is clearly documented 
Changes in grain size in Baldeggersee sediments are primarily due to changes in the calcite size. Calcites are well preserved in eutrophic hard-water lakes. A case study based on sediment traps in neighbouring Sempachersee has shown that calcite dissolution in the water column is as small as $5 \%$ of the sedimentation rate. At the water-sediment interface only about $2 \%$ of the calcite flux is lost to the overlying water (Urban et al., 1996; Wehrli et al., 1997). Brunskill (1969), Kelts and Hsü (1978), Sturm (1985), Koschel et al. (1987), and others have shown that calcites are sensitive indicators of seasonal productivity variations in hard-water lakes. Lotter (1989) and Sturm and Lotter (1995) have used this evidence to prove the annual nature of lamination of long varved sequences. But, even more important, grain size of calcites can be used as proxy indicator of former trophic state and nutrient condition of a lake as shown by Niessen and Sturm (1987). The correlation between MGS and the available total phosphorus concentration in Baldeggersee between 1950 and 1992 is highly significant $(r=0.55 ; \mathrm{p}<0.05)$. Furthermore, the high positive correlation between MGS and the TOC concentration in the sediment (Table 4) also indicates that there is a relationship between trophic state and MGS.

Growth of calcites is inhibited when $\mathrm{PO}_{4}$ is present in the lake water (Kunz and Stumm, 1984; Dove and Hochella, 1993). The $\mathrm{PO}_{4}$ concentration is largest in spring and, as it inhibits carbonate precipitation, leads to supersaturation of carbonate in the lake. After the first algal bloom, nutrients are substantially reduced in the lake water, which allows fast precipitation of large, idiomorphic calcites showing heterogeneous nucleation. During summer, when $\mathrm{PO}_{4}$ concentrations decrease, precipitation of much smaller, microcrystalline, homogeneously nucleated calcites takes place (Kunz and Stumm, 1984). This relation of calcite sizes and phosphorus concentrations was first used by Niessen and Sturm (1987) for an estimation of the trophic evolution of Baldeggersee.

\section{Eutrophication history}

The annually laminated sediments of Baldeggersee represent an unique and highresolution archive of the anthropogenically induced eutrophication history of this lake during the last century. Based on lithological, geochemical and grain-size analyses results, the following eutrophication scenario can be drawn: Before 1885 packets of 5-10 light/dark couplets that are interrupted by homogeneous marl beds (Table 1) indicate oscillating hypolimnetic oxygen conditions. Since 1885 the lake has been constantly anoxic in its deepest part due to oxygen consumption for the mineralization of dead biomass. At the turn of the century fine grained, microcrystalline calcites were formed. Increases in varve thickness between 1905 and 1910, as well as a first increase in calcite grain-size occurring in 1909/1910, are the result of an important step in eutrophication that is also evident in the subfossil diatom assemblages (Lotter, in press).

Between 1910 and 1950 precipitation of coarser calcites occurred as a consequence of increasing eutrophication of the lake. Starting in the mid-1930s nitrogen concentrations steadily increased until they levelled off in the early 1960s, reflecting high levels of primary production and enhanced preservation of organic matter due to hypolimnetic anoxia. Since the late 1950s the phosphorus content of 
the sediment also increased significantly. Intensive land-use, an increase in human population as well as an increasing inflow of untreated sewage effluents resulted in a severe increase in the nutrient load. Phosphorus concentrations in the lake water increased during this period from $80{\mu \mathrm{g} \mathrm{l}^{-1}}^{-1}$ to $>500 \mu \mathrm{g} \mathrm{l}^{-1}$ (Stadelmann et al., 1994; Wehrli et al., 1997). Likewise, the median grain sizes of calcites increased from $6 \mu \mathrm{m}$ to $16 \mu \mathrm{m}$ (Fig. 10). Reduction of phosphorus concentrations in the lake water to about $90 \mu \mathrm{g} \mathrm{l}^{-1}$ by external (construction of sewage treatment plants and introduction of stricter effluent laws in 1967) and internal (diffusive influx of air and oxygen respectively in 1982) restoration measures subsequently induced a significant decrease of calcite sizes back to about $8 \mu \mathrm{m}$. Median grain sizes of the most recent sediments indicate, however, that the trophic state of Baldeggersee has not yet reached pre-1950 levels (Fig. 10).

\section{ACKNOWLEDGEMENTS}

We would like to thank A. Zwyssig and B. Wilke for their help during field work, C. Stengel, T. Schaller, D. Olson, and E. Nelson for their endurance during sampling in the freeze-room, and C. Stengel for the geochemical analyses. We greatfully acknowledge three anonymous reviewers for their comments on an earlier version of the manuscript. This study was supported by Swiss National Science Foundation through National Research Program 31 project 4031-33147 and Priority Programme Environment project 5001-34876 and is a contribution to the IGCP 374 project "Palaeoclimatology and Palaeoceanography from Late Quaternary and Holocene Laminated Sediments". JLT has been supported by an ETH L+F grant.

\section{REFERENCES}

Björck, S., B. Kromer, S. Johnsen, O. Bennike, D. Hammarlund, G. Lemdahl, G. Possnert, T. L. Rasmussen, B. Wohlfarth, C. U. Hammer and M. Spurk, 1996. Synchronized terrestrial-atmospheric deglacial records around the North Atlantic. Science 274:1155-1160.

Brunskill, G. J., 1969. Fayetteville Green Lake, New York. II. Precipitation and sedimentation of calcite in a meromictic lake with laminated sediments. Limnol. Oceanogr. 14:830-847.

Canfield, D. E., 1994. Factors influencing organic carbon preservation in marine sediments. Chem. Geol. 114:315-329.

Crusius, J. and R. F. Anderson, 1995. Evaluating the mobility of ${ }^{137} \mathrm{Cs},{ }^{249+240} \mathrm{Pu}$ and ${ }^{210} \mathrm{~Pb}$ from their distribution in laminated sediments. Journal of Paleolimnology 13:119-141.

De Geer, G., 1912. A geochronology of the last 12000 years. Proc. 11th Internat. Geological Congress 1910:241-253.

Dickman, M., 1985. Seasonal succession and microlamina formation in a meromictic lake displaying varved sediments. Sedimentology 32:109-118.

Dove, P.M. and M.F. Hochella, 1993. Calcite precipitation mechanisms and inhibition by orthophosphate: in situ observations by scanning force microscopy. Geochim. Cosmochim. Acta 57:705-714.

Furrer, G. and B. Wehrli, 1996. Microbial reactions, chemical speciation, and multicomponent diffusion in porewaters of a eutrophic lake. Geochim. Cosmochim. Acta 60:2333-2346.

Geyh, M. A., J. Merkt and H. Müller, 1971. Sediment-, Pollen- und Isotopenanalysen an jahreszeitlich geschichteten Ablagerungen im zentralen Teil des Schleinsees. Arch. Hydrobiol. 69:366-399.

Goslar, T., T. Kuc, M. Ralska-Jasiewiczowa, K. Rozanski, M. Arnold, E. Bard, B. van Geel, M. F. Pazdur, K. Szeroczynska, B. Wicik, K. Wieckowski and A. Walanus, 1993. High-resolution lacustrine record of the Late Glacial/Holocene transition in Central Europe. Quaternary Science Reviews 12:287-294. 
Goslar, T., M. Arnold, E. Bard, T. Kuc, M. F. Pazdur, M. Ralska-Jasiewiczowa, K. Rozanski, N. Tisnerat, A. Walanus, B. Wicik and K. Wieckowski, 1995. High concentration of atmospheric 14-C during the Younger Dryas cold episode. Nature 377:414-417.

Hajdas, I., S. D. Ivy, J. Beer, G. Bonani, D. Imboden, A. F. Lotter, M. Sturm and M. Suter, 1993. AMS radiocarbon dating and varve chronology of lake Soppensee: 6000 to $12,000{ }^{14} \mathrm{C}$ years BP. Climate Dynamics 9:107-116.

Henrichs, S. M., 1992. Early diagenesis of organic matter in marine sediments: progress and perplexity. Mar. Chem. 39:119-149.

Hupfer, M., R. Gächter and R. Giovanoli, 1995. Transformation of phosphorus species in settling seston and during early diagenesis. Aquatic Sciences 57:305-324.

Itkonen, A. and V.-P. Salonen, 1994. The response of sedimentation in three varved lacustrine sequences to air temperatures, precipitation and human impact. Journal of Paleolimnology 11:323-332.

Kelts, K. and K. J. Hsü, 1978. Freshwater carbonate sedimentation. In: "Lakes. Geology, Chemistry, Physics." (A. Lerman, Ed.), Springer Verlag, New York. 295-323.

Koschel, R., G. Proft and H. Raidt, 1987. Autochthone Kalkfällung in Hartwasserseen der Mecklenburger Seenplatte. Limnologica 18:317-338.

Kunz, B. and W. Stumm, 1984. Kinetik der Bildung und des Wachstums von Calciumcarbonat. Vom Wasser 62:279-293.

Lamoureux, S. F., 1994. Embedding unfrozen lake sediments for thin section preparation. Journal of Paleolimnology 10:141-146.

Leemann, A., F. Niessen and M. Sturm, 1991. Rhythmite in alpinen Vorgletscherseen - Warvenstratigraphie und Speicherung von Klimainformation. Zbl. Geol. Paläont. Teil I 12:29632976.

Lotter, A. F., 1989. Evidence of annual layering in Holocene sediments of Soppensee, Switzerland. Aquatic Sciences 51:19-30.

Lotter, A. F. The recent eutrophication of Baldeggersee (Switzerland) as assessed by fossil diatom assemblages. The Holocene: in press

Lotter, A. F., B. Ammann and M. Sturm, 1992. Rates of change and chronological problems during the late-glacial period. Climate Dynamics 6:233-239.

Lotter, A. F. and M. Sturm, 1993. The study of environmental dynamics by means of laminated sediments; results from Switzerland. PACT 41:15-24.

Lotter, A. F., I. Renberg, H. Hansson, R. Stöckli and M. Sturm, 1997 a. A remote controlled freeze corer for sampling of unconsolidated surface sediments. Aquatic Sciences 59:295-303.

Lotter, A. F., J. Merkt and M. Sturm, 1997b. Differential sedimentation versus coring artifacts: a comparison of two widely used piston-coring methods. Journal of Paleolimnology 18:75-85.

Lotter, A. F. and H. J. B. Birks, 1997. The separation of the influence of nutrients and climate on the varve time-series of Baldeggersee, Switzerland. Aquatic Sciences 59:362-375.

Mayer, L. M., 1994. Relationships between mineral surfaces and organic carbon concentrations in soils and sediments. Chem. Geol. 114:347-363.

Niessen, F. and M. Sturm, 1987. Die Sedimente des Baldeggersees (Schweiz) - Ablagerungsraum und Eutrophierungsentwicklung während der letzten 100 Jahre. Arch. Hydrobiol. 108: $365-383$.

Nipkow, F., 1927. Über das Verhalten der Skelette planktischer Kieselalgen im geschichteten Tiefenschlamm des Zürich- und Baldeggersees. Thesis, ETH Zürich.

O'Sullivan, P. E., 1983. Annually-laminated lake sediments and the study of Quaternary environmental changes - a review. Quaternary Science Reviews 1:245-313.

Peglar, S. M., 1993. The mid-Holocene Ulmus decline at Diss Mere, Norfolk, U. K.: a year-by-year pollen stratigraphy from annual laminations. The Holocene 3:1-13.

Perkins, J.A. and J.D. Sims, 1983. Correlation of Alaskan varve thickness with climatic parameters, and use in paleoclimatic reconstruction. Quaternary Research 20:308-321.

Ralska-Jasiewiczowa, M., B. Wicik and K. Wieckowski, 1987. Lake Gosciaz - a site of annually laminated sediments covering 12000 years. Bulletin Polish Academy of Science, Earth Science 35:127-137.

Renberg, I., U. Segerström and J.-E. Wallin, 1984. Climatic reflection in varved lake sediments. In "Climatic changes on a Yearly to Millennial Basis." (N.-A. Mörner and W. Karlén, Eds.), Reidel. 249-256. 
Schaller, T. and B. Wehrli, 1996. Geochemical focusing of manganese in lake sediments - an indicator of deep-water oxygen conditions. Aquatic Geochemistry 2:359-378.

Schaller, T., H. C. Moor and B. Wehrli, 1997. Sedimentary profiles of Fe, Mn, V, Cr, As and Mo recording signals of changing deep-water oxygen conditions in Baldeggersee. Aquatic Sciences 59:345-361.

Simola, H., 1992. Structural elements in varved lake sediments. Geological Survey of Finland Spec. Paper 14:5-9.

Simola, H., I. Hanski and M. Liukkonen, 1990. Stratigraphy, species richness and seasonal dynamics of plankton diatoms during 418 years in Lake Lovojärvi, South Finland. Annales Botanici Fennici 27:241-259.

Simola, H., P. Huttunen and J. Meriläinen, 1986. Techniques for sediment freezing and treatment of frozen sediment samples. Univ. Joensuu, Publications of Karelian Institute 79:99-107.

Spengeler, R., 1994. Die Sanierung des Baldeggersees: Besiedlung des Benthals durch Oligochaeten und Chironomiden 12 Jahre nach Beginn der seeinternen Massnahmen. Diploma Thesis, ETH Zürich.

Stadelmann, P., P. Herzog, P. Arnold, J. C. Bernegger, E. Butscher, F. Hirsiger and P. Koller, 1994. Sanierung des Baldegger- und Hallwilersees und deren Einzugsgebiete. Situationsanalyse und Rechenschaftsbericht zuhanden des Gemeindeverbandes Baldegger- und Hallwilersee. Luzern, Kantonales Amt für Umweltschutz.

Sturm, M., 1985. Schwebstoffe in Seen. Mitt. EAWAG 19:9-15.

Sturm, M. and A.F. Lotter, 1995. Lake sediments as environmental archives. EAWAG News $38(\mathrm{E}): 6-9$.

Svensson, J.M. and L. Leonardson, 1996. Effects of bioturbation by tube-dwelling chironomid larvae on oxygen uptake and denitrification in eutrophic lake sediments. Freshwater Biology $35: 289-300$.

Urban, N. R., C. Dinkel and B. Wehrli, 1996. Solute transfer across the sediment-water surface of a eutrophic lake: I. Porewater profiles from dialysis samplers. Aquatic Sciences 59:1-25.

Urban, N. R., R. Gächter and J. Bloesch, 1997. The significance of C:N ratios in particles in lakes. Limnol. Oceanogr:: in press.

Wehrli, B., A. F. Lotter, T. Schaller and M. Sturm, 1997. High-resolution varve studies in Baldeggersee (Switzerland): project overview and limnological background data. Aquatic Sciences 59:285-294.

Wieland, E., P.H. Santschi, P. Höhener and M. Sturm, 1993. Scavenging of Chernobyl ${ }^{137}$ Cs and natural ${ }^{210} \mathrm{~Pb}$ in Lake Sempach, Switzerland. Geochimica et Cosmochimica Acta 57: 2959-2979.

Wohlfarth, B., S. Björck, G. Possnert, G. Lemdahl, L. Brunnberg, J. Ising, J. Olsson and N.-O. Svensson, 1993. AMS dating Swedish varved clays of the last glacial/interglacial transition and the potential/difficulties of calibrating Late Weichselian "absolute" chronologies. Boreas 22: $113-128$.

Zolitschka, B., 1996. High resolution lacustrine sediments and their potential for palaeoclimatic reconstruction. Climatic variations and forcing mechanisms of the last 2000 years. (P. D. Jones, R.S. Bradley and J. Jouzel, eds.) High resolution lacustrine sediments and their potential for palaeoclimatic reconstruction. Berlin, Springer Verlag. NATO ASI Series, I 41:453-478.

Received 8 January 1997;

revised manuscript accepted 17 July 1997. 